\title{
Salt - A Potential ‘Uremic Toxin’?
}

\section{Eberhard Ritz Ralf Dikow Christian Morath Vedat Schwenger}

Department of Internal Medicine, Ruperto Carola University Heidelberg, Heidelberg, Germany

\section{Key Words}

Left ventricular hypertrophy · Aortic stiffness •

Oxidative stress $\cdot$ Aldosterone

\begin{abstract}
It has been known for decades that salt ( $\mathrm{NaCl})$ determines extracellular volume as well as blood pressure and is one cause of hypertension. The difficulty to control the $\mathrm{NaCl}$ balance and thus treat sodium overload and hypertension in patients on dialysis has been recognized by Scribner in the early days of dialysis. In recent years, an impressive body of evidence has accumulated indicating that in essential hypertension, $\mathrm{NaCl}$ - blood pressure independently - causes target organ damage such as left ventricular hypertrophy, microalbuminuria, and increased aortic stiffness. It has further been recognized that $\mathrm{NaCl}$ increases oxidative stress and, again blood pressure independently, amplifies tissue injury induced by aldosterone. In renal damage models, progression is dramatically accelerated by high $\mathrm{NaCl}$ intake. Sodium as a potential culprit in progression to target organ damage in terminal renal failure has not been well investigated so far. However, it is possible, and indeed likely, that sodium plays an adverse role in the genesis of target organ damage in terminal renal failure.
\end{abstract}

Copyright @ 2006 S. Karger AG, Basel

\section{Cultural History of Salt}

When reading current literature on salt, one is amazed how emotional discussions on this issue continue to be. Although admittedly much of the published evidence is poor, thus generating controversy, the emotions presumably are also due to the fact that in the past salt had profoundly influenced human thinking and lifestyle in a way which is no longer appreciated today after salt has become an easily accessible commodity. Nevertheless, perhaps subconsciously, salt has remained a substance which is not emotionally 'neutral' [1], possibly a reflection of the profound symbolic significance attached to salt for millennia.

For times immemorial when salt was an extremely precious item it had numerous connotations, both positive and negative [1]. Salt was a symbol of purity and loyalty (e.g., contracts were sealed with salt) [The Bible, Moses IV;18,19; Chronicles II;13,15], of trust (e.g., the guest was greeted with bread and salt), but also of libido and sexuality (e.g., Venus saligena, the salt-born Venus).

The immense economic importance of salt is illustrated by the numerous place names linked to salt such as Salzburg (German: Salz) and Hallein (Keltic: hal). In England, place names with the ending 'wich', e.g. Sandwich, point to past saltworks. Protest against the heavy salt tax (gabelle) was an important cause, today largely forgotten, which had triggered the French Revolution and later the Indian Rebellion under Mahatma Gandhi [2].

The physiological importance of salt is illustrated by the phenomenon of 'salt hunger' which has been well studied in the animal kingdom [3,4] and is documented for humans by archeological studies and historical records $[1,5]$. In animal husbandry, salt intake determines for instance the success of pregnancy and the resistance against hypotension and shock [3].

Human societies have experienced a change from the threat of salt deficiency to that of salt overload: compared

\section{KARGER}

Fax +4161306 1234 E-Mail karger@karger.ch www.karger.com
(C) $2006 \mathrm{~S}$. Karger AG, Basel

$0253-5068 / 06 / 0241-0063 \$ 23.50 / 0$

Accessible online at: www.karger.com/bpu
Prof. Dr. Eberhard Ritz

Department of Internal Medicine, Nierenzentrum

Ruperto Carola University Heidelberg, Im Neuenheimer Feld 162 DE-69120 Heidelberg (Germany)

Tel. +496221601705, Fax +496221603302, E-Mail prof.e.ritz@t-online.de 
with the estimated salt intake of our ancestors of 1-3 g/ day $\mathrm{NaCl}$ [5], today, the average salt intake is $10-15 \mathrm{~g}$ /day in Western societies [2].

\section{Salt and Hypertension}

In genetically predisposed individuals, salt is a pernicious factor for the onset and progression of hypertension, as beautifully illustrated by the monkey experiments of Denton et al. [6]. The customary high salt intake causes increased blood pressure, as shown by intervention studies, particularly the Dietary Approaches to Stop Hypertension study [7], and documented by recent meta-analyses $[8,9]$. The blood pressure response depends on the so-called salt sensitivity which is in part genetically determined, but also modified by conditions such as advanced age, obesity, diabetes mellitus, and particularly, renal malfunction. It is of interest that salt appetite is primed early on in life [10]: in children raised on low-salt baby food, permanently lower blood pressures and reduced salt appetite are noted. But even in adults, salt appetite slowly adapts to modification of salt intake.

The mechanisms through which salt increases blood pressure are complex. According to Guyton [11] and Guyton and Coleman [12], a positive salt balance raises osmotic pressure, increases water intake and thus rapidly causes hypervolemia. However, in the long run, the increase in peripheral vascular resistance through the process of autoregulation becomes the dominant determinant of blood pressure. The clinical equivalent of this slow adaptive process in dialysis patients is the 'lag phase'; it takes several weeks before the full impact of changes in volemia translate into changes of blood pressure [13]. Even the above paradigm of Guyton may not do full justice to the complexity of the problem, since recently, nonosmotic storage of salt has also been well documented [14].

\section{Salt and Blood Pressure-Independent Cardiovascular and Renal Target Organ Damage}

It has been amply documented that ventricular hypertrophy $[15,16]$ but also characteristics of the vasculature such as pulse pressure and vascular stiffness [17] are influenced by salt intake independent of blood pressure or amplifying the response to high blood pressure. A study in Finland showed that high salt intake translates into higher cardiovascular mortality in the general population [18].

Even more interesting to the nephrologist is the recent documentation which showed that renal lesions and progression are aggravated by high salt intake in different renal damage models [19] as varied as glomerulonephritis [20], subtotal nephrectomy [21], allograft nephropathy [22], or nephron underdosing after intrauterine stress [23]. The effect of high dietary sodium in promoting fibrosis and other lesions is not restricted to the kidney, but is also seen for instance in the heart [24]. In population studies, it has been shown that even urinary albumin excretion in the microalbuminuric range is related to sodium intake [25]. There are also retrospective data suggesting, but not proving, that the rate of progression is lower at less habitual dietary intakes of sodium chloride [26]. In this respect, the observation of Benstein et al. [21] showed that in a remnant kidney model the effect of dietary salt restriction cannot be completely imitated by diuretic treatment.

What are the underlying pathomechanisms? The effects of angiotensin II and aldosterone [27, 28] are known to be amplified by a high salt intake. However, direct and blood pressure-independent effects of high salt intake have been identified: within 1 day and without change in blood pressure, high salt intake causes increased transforming growth factor- $\beta$ expression in kidney and aortic endothelial cells. The blood pressure response to high salt has been shown to be determined by the availability of nitric oxide, and interestingly, endogenous nitric oxide synthase is stimulated by transforming growth factor- $\beta$. Salt, perhaps as a result of increased shear stress, has numerous effects on endothelial cell mitogen-activated protein kinase and SMAD signaling [19] making endothelial cells hot candidates for salt-induced organ damage.

\section{Effect of Salt Intake and Salt Balance on Dialysis}

What is known about the role of sodium in dialysis patients? Two weeks after maintenance hemodialysis has been introduced by Scribner et al. [29, 30], they indicated several problems that still plague us today: 'As in the case of nephrectomized dogs, hypertension appears to be influenced by the size of the extracellular space. The combination of dietary sodium restriction and ultrafiltration during dialysis permits regulation of extracellular volume.' 
Subsequently, the importance of controlling overhydration was no longer on the radar screen of many nephrologists, not to the least because of logistic and financial constraints to shorten the duration of dialysis sessions. Particularly dietary salt restriction had to a large extent become the Cinderella in the management of dialysis patients [31]. Recently, measurements of atrial natriuretic peptide and brain natriuretic peptide have documented how frequently hypervolemia is present even in patients who on clinical grounds were thought to have achieved dry weight.

On the other hand, in well-documented observations, normotension could be achieved by the above interventions without antihypertensive medication in more than $90 \%$ of dialysis patients [32]. Even regression of left ventricular hypertrophy is possible by limiting salt intake and control of hypervolemia with aggressive ultrafiltration [33-35].

\section{Salt and Target Organ Damage in Dialysis Patients}

Surprisingly, in view of the vast information on the effect of salt on renal and cardiac target organ damage $[15,19,24,36]$, little is known about potential effects of sodium on target organ damage in uremia. Let us just mention one example.
Today, increased aortic stiffness has been recognized as an important determinant of increased cardiovascular risk [37]. Sodium/volume overload is related to aortic stiffness. Tycho Vuurmans et al. [38] administered angiotensin-converting enzyme inhibitors to dialysis patients and were able to show that this reduced, but failed to normalize, aortic pulse wave velocity as an index of vascular stiffness. Complete normalization was only achieved with combined volume control plus pharmacological blockade of the renin angiotensin system.

This is one of the few documented examples showing the importance of salt/volume in target organ malfunction, but one has to admit that the issue has not been investigated with the rigor which it deserves.

One of the mediators (but not the only one) is oxidative stress. Oxidative stress is also one of the hallmarks of renal failure [39]. Numerous experimental studies documented induction or amplification of oxidative stress by salt $[19,40]$, a phylogenetically ancient reaction [41, 42], and reversal of organ damage in salt-sensitive models of tissue injury by antioxidative intervention [43, 44].

We propose the hypothesis that salt excess increases oxidative stress (possibly also by other mechanisms) and thus amplifies uremic 'toxicity'. Conversely, we suggest that restriction of dietary salt intake and control of salt overload by ultrafiltration would reduce oxidative stress and target organ damage. This hypothesis is susceptible to verification or falsification.

\section{References}

1 Bergier JF: Une Histoire du Sel. Fribourg, Office du Livre SA, 1982.

-2 Ritz E: The history of salt - Aspects of interest to the nephrologist. Nephrol Dial Transplant 1996;11:969-975.

3 Denton D: The Hunger for Salt. Berlin, Springer, 1984.

-4 Weisinger RS, Blair-West JR, Burns P, Denton DA, McKinley MJ, Tarjan E: The role of angiotensin II in ingestive behaviour: a brief review of angiotensin II, thirst and $\mathrm{Na}$ appetite. Regul Pept 1996;66:73-81.

5 Abrams HL Jr: Salt and sodium: an anthropological cross cultural perspective in health and disease. J Appl Nutr 1983;35:127-158.

-6 Denton D, Weisinger R, Mundy NI, Wickings EJ, Dixson A, Moisson P, Pingard AM, Shade R, Carey D, Ardaillou R, et al: The effect of increased salt intake on blood pressure of chimpanzees. Nat Med 1995;1:1009-1016.

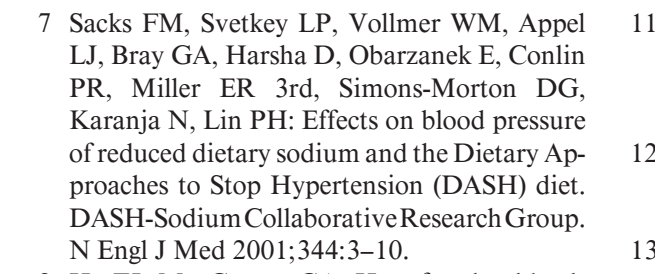

-8 He FJ, MacGregor GA: How far should salt intake be reduced? Hypertension 2003;42: 1093-1099.

9 He J, Ogden LG, Vupputuri S, Bazzano LA, Loria C, Whelton PK: Dietary sodium intake and subsequent risk of cardiovascular disease in overweight adults. JAMA 1999;282:20272034.

10 Geleijnse JM, Hofman A, Witteman JC, Hazebroek AA, Valkenburg HA, Grobbee DE: Long-term effects of neonatal sodium restriction on blood pressure. Hypertension 1997;29: 913-917.
Guyton AC: Dominant role of the kidneys and accessory role of whole-body autoregulation in the pathogenesis of hypertension. Am J Hypertens 1989:2:575-585.

12 Guyton AC, Coleman TG: Quantitative analysis of the pathophysiology of hypertension. 1969. J Am Soc Nephrol 1999;10:2248-2258.

13 Charra B, Bergstrom J, Scribner BH: Blood pressure control in dialysis patients: importance of the lag phenomenon. Am J Kidney Dis 1998;32:720-724.

14 Titze J, Shakibaei M, Schafflhuber M, SchulzeTanzil G, Porst M, Schwind KH, Dietsch P, Hilgers KF: Glycosaminoglycan polymerization may enable osmotically inactive $\mathrm{Na}^{+}$storage in the skin. Am J Physiol Heart Circ Physiol 2004;287:H203-H208.

15 Messerli FH, Schmieder RE, Weir MR: Salt. A perpetrator of hypertensive target organ disease? Arch Intern Med 1997;157:2449-2452. 
16 du Cailar G, Mimran A: Sodium and left ventricular hypertrophy in patients with hypertension. Arch Mal Coeur Vaiss 1995;88:15-19.

-17 du Cailar G, Mimran A, Fesler P, Ribstein J, Blacher J, Safar ME: Dietary sodium and pulse pressure in normotensive and essential hypertensive subjects. J Hypertens 2004;22:697703.

-18 Tuomilehto J, Jousilahti P, Rastenyte D, Moltchanov V, Tanskanen A, Pietinen P, Nissinen A: Urinary sodium excretion and cardiovascular mortality in Finland: a prospective study. Lancet 2001;357:848-851.

19 Sanders PW: Salt intake, endothelial cell signaling, and progression of kidney disease. Hypertension 2004;43:142-146.

-20 Suzuki H, Yamamoto T, Ikegaya N, Hishida A: Dietary salt intake modulates progression of antithymocyte serum nephritis through alteration of glomerular angiotensin II receptor expression. Am J Physiol Renal Physiol 2004; 286:F267-F277.

21 Benstein JA, Feiner HD, Parker M, Dworkin LD: Superiority of salt restriction over diuretics in reducing renal hypertrophy and injury in uninephrectomized SHR. Am J Physiol 1990; 258:F1675-F1681.

-22 Sanders PW, Gibbs CL, Akhi KM, MacMillanCrow LA, Zinn KR, Chen YF, Young CJ, Thompson JA: Increased dietary salt accelerates chronic allograft nephropathy in rats. Kidney Int 2001;59:1149-1157.

-23 Sanders MW, Fazzi GE, Janssen GM, Blanco CE, De Mey JG: High sodium intake increases blood pressure and alters renal function in intrauterine growth-retarded rats. Hypertension 2005; 46:71-75.

$24 \mathrm{Yu}$ HC, Burrell LM, Black MJ, Wu LL, Dilley RJ, Cooper ME, Johnston CI: Salt induces myocardial and renal fibrosis in normotensive and hypertensive rats. Circulation 1998;98: 2621-2628.

25 Verhave JC, Hillege HL, Burgerhof JG, Janssen WM, Gansevoort RT, Navis GJ, de Zeeuw $\mathrm{D}$, de Jong PE: Sodium intake affects urinary albumin excretion especially in overweight subjects. J Intern Med 2004;256:324-330.
26 Cianciaruso B, Bellizzi V, Minutolo R, Tavera A, Capuano A, Conte G, De Nicola L: Salt intake and renal outcome in patients with progressive renal disease. Miner Electrolyte Metab 1998;24:296-301

27 Rocha R, Funder JW: The pathophysiology of aldosterone in the cardiovascular system. Ann NY Acad Sci 2002;970:89-100.

28 Joffe HV, Adler GK: Effect of aldosterone and mineralocorticoid receptor blockade on vascular inflammation. Heart Fail Rev 2005; 10:3137.

-29 Scribner BH, Buri R, Caner JE, Hegstrom R, Burnell JM: The treatment of chronic uremia by means of intermittent hemodialysis: a preliminary report. Trans Am Soc Artif Intern Organs 1960;6:114-122.

30 Scribner BH, Buri R, Caner JE, Hegstrom R, Burnell JM: The treatment of chronic uremia by means of intermittent hemodialysis: a preliminary report. 1960. J Am Soc Nephrol 1998 9:719-726.

31 Dorhout Mees EJ: Volaemia and blood pressure in renal failure: have old truths been forgotten. Nephrol Dial Transplant 1995; 10 1297-1298.

- 32 Charra B, Calemard E, Ruffet M, Chazot C, Terrat JC, Vanel T, Laurent G: Survival as an index of adequacy of dialysis. Kidney Int 1992 41:1286-1291.

33 Ozkahya M, Ok E, Cirit M, Aydin S, Akcicek F, Basci A, Dorhout Mees EJ: Regression of left ventricular hypertrophy in haemodialysis patients by ultrafiltration and reduced salt intake without antihypertensive drugs. Nephrol Dia Transplant 1998;13:1489-1493.

34 Ozkahya M, Toz H, Qzerkan F, Duman S, Ok E, Basci A, Mees EJ: Impact of volume control on left ventricular hypertrophy in dialysis patients. J Nephrol 2002;15:655-660.

- 35 Krautzig S, Janssen U, Koch KM, Granolleras C, Shaldon S: Dietary salt restriction and reduction of dialysate sodium to control hypertension in maintenance haemodialysis patients. Nephrol Dial Transplant 1998;13. 552-553.

36 du Cailar G, Gallay P, Ribstein J, Daures JP, Grolleau R, Mimran A: Myocardial morphological changes related to sodium intake in normotensive and hypertensive patients never treated before. Arch Mal Coeur Vaiss 1990;83: 2045-2049.
37 London GM, Marchais SJ, Guerin AP, Metivier $\mathrm{F}$, Adda $\mathrm{H}$ : Arterial structure and function in end-stage renal disease. Nephrol Dial Transplant 2002;17:1713-1724.

38 Tycho Vuurmans JL, Boer WH, Bos WJ, Blankestijn PJ, Koomans HA: Contribution of volume overload and angiotensin II to the increased pulse wave velocity of hemodialysis patients. J Am Soc Nephrol 2002;13:177183.

- 39 Oberg BP, McMenamin E, Lucas FL, McMonagle E, Morrow J, Ikizler TA, Himmelfarb $\mathrm{J}$ : Increased prevalence of oxidant stress and inflammation in patients with moderate to severe chronic kidney disease. Kidney Int 2004; 65:1009-1016.

-40 Kitiyakara C, Chabrashvili T, Chen Y, Blau J, Karber A, Aslam S, Welch WJ, Wilcox CS: Salt intake, oxidative stress, and renal expression of NADPH oxidase and superoxide dismutase. J Am Soc Nephrol 2003; 14:2775-2782.

41 Takahashi S, Seki M, Ishida J, Satou M, Sakurai T, Narusaka M, Kamiya A, Nakajima M, Enju A, Akiyama K, Yamaguchi-Shinozaki K, Shinozaki K: Monitoring the expression profiles of genes induced by hyperosmotic, high salinity, and oxidative stress and abscisic acid treatment in Arabidopsis cell culture using a full-length cDNA microarray. Plant Mol Biol 2004;56:29-55.

42 Chaparzadeh N, D’Amico ML, Khavari-Nejad RA, Izzo R, Navari-Izzo F: Antioxidative responses of Calendula officinalis under salinity conditions. Plant Physiol Biochem 2004;42: 695-701.

43 Kushiro T, Fujita H, Hisaki R, Asai T, Ichiyama I, Kitahara Y, Koike M, Sugiura H, Saito F, Otsuka Y, Kanmatsuse K: Oxidative stress in the Dahl salt-sensitive hypertensive rat. Clin Exp Hypertens 2005;27:9-15.

44 Tian N, Thrasher KD, Gundy PD, Hughson MD, Manning RD Jr: Antioxidant treatment prevents renal damage and dysfunction and reduces arterial pressure in salt-sensitive hypertension. Hypertension 2005;45:934-939. 